\title{
A review of liver disorders in inflammatory bowel disease (IBD)
}

\author{
Niraj James Shah ${ }^{1 *}$, Nitin K Gupta ${ }^{2}$ and Brian B Borg ${ }^{3}$ \\ ${ }^{1}$ Department of Medicine, Division of Digestive Diseases, The University of Mississippi Medical Center, USA \\ ${ }^{2}$ Director of inflammatory Bowel Disease, School of Medicine, Department of Medicine, Division of Digestive Diseases, The University of Mississippi Medical \\ Center, USA \\ ${ }^{3}$ Director of Hepatology, Medical Director of Liver Transplant, School of Medicine, Department of Medicine, Division of Digestive Diseases, The University of \\ Mississippi Medical Center, USA
}

\begin{abstract}
Disorders of the liver and the biliary tract are frequently the extraintestinal manifestations of inflammatory bowel disease (IBD). The etiology of these hepato-biliary conditions is deemed secondary to their shared pathogenesis, the chronic effects of a long term, ongoing inflammation of the bowels, along with the medications used to manage IBD. For up to $30 \%$ of patients with IBD, abnormal liver biochemical tests are present. Other, selected patients with IBD are followed for reactivation of hepatitis B, through guidelines only relatively recently in place. The vast realm of related clinical conditions does not always correspond well with IBD severity, which can range from mild hepatic insult to end-stage liver disease, necessitating liver transplantation. Hence it is critical to follow its presence, clinical course and long term consequences. Moreover, the management of these disorders is necessarily individualized, with some patients requiring frequent monitoring and others a more multi-disciplinary approach. Studies aimed at improving the outcomes of patients with IBD who experience associated liver and biliary tract disorders are now needed to assess early identification, possible screening approaches and more effective systems of referral. This article covers the evidence-based literature on topics detailing the co-existence of liver conditions in inflammatory bowel disease with a focus on its epidemiology, clinical manifestations, diagnosis and management.
\end{abstract}

\section{Introduction}

Although it would lack biopsy confirmation until the mid- $20^{\text {th }}$ century, published accounts of inflammatory bowel disease (IBD) were in circulation in the early $19^{\text {th }}$ century suggesting evidence for an association between hepatobiliary disorders and IBD. This evidence has now immensely expanded, with hepatobiliary disease in IBD now known to constitute some of the disorder's most common extraintestinal manifestations [1-8]. Also, these hepatobiliary manifestations do not always parallel IBD disease activity, but instead may follow an independent natural course [5].

The most specific hepatobiliary complication associated with IBD is primary sclerosing cholangitis (PSC). Nonalcoholic fatty liver disease (NAFLD), however, is its most common manifestation. Liver toxicity arising from IBD-related medications is also common [9-15], as is hepatitis $\mathrm{B}$ reactivation, secondary to the use of immunosuppressive agents, including biologics. Given the high risk implicated for these agents, regular hepatitis B screening has been suggested for this subgroup. Relatively recent studies have also suggested that the emergence of obesity has changed the phenotype of the IBD population $[16,17]$, with greater numbers of patients with IBD having NAFLD. Other, less common, hepatobiliary manifestations of IBD include cholelithiasis, autoimmune hepatitis, hepatic abscess, IgG4-associated cholangitis, portal vein thrombosis, granulomatous hepatitis and primary biliary cholangitis. Finally, comparative studies of the prevalence of cholelithiasis, PSC and fatty liver in the general population $(1.8 \%$ $22.4 \%$, not applicable, 6\%-35\%) indicate a higher prevalence in Ulcerative Colitis (4.6\%-36.4\%, 0.76\%-5.4\%, 1.5\%-55\%) and Crohn's Disease (11\%-34\%, 1.2\%-3.4\%, 1.5\%-39.5\%) [18].

\section{Materials and methods}

\section{Literature search}

We conducted online electronic searches of manuscripts published by PubMed and the Cochrane Library. We also conducted manual searches of selected specialty journals to identify any pertinent literature. The search was conducted using the key words 'inflammatory bowel disease', liver diseases', 'ulcerative colitis', 'crohn's disease', 'primary sclerosing cholangitis', 'drug induced liver injury', and 'hepatitis B'. The references of articles were reviewed to identify additional articles. Studies not published in English were excluded.

\section{Abnormal liver test in IBD}

As about $30 \%$ of patients with IBD are reported to have an abnormal liver biochemical profile, either transient (due to IBD activity) or persistent [19], a systematic approach to excluding common liver conditions unrelated to IBD should be considered [20]. At a minimum, all patients with IBD should be screened for viral

Correspondence to: Niraj James Shah, MD, Assistant Professor of Medicine, Department of Medicine, Division of Digestive Diseases, The University of Mississippi Medical Center, 2500 North State Street, Jackson, MS 39216, USA, Tel: 001-601-984-4540 (extension 7915); Fax: 001- 601-984-4548; E-mail: jnshah@umc.edu,nirajjames@gmail.com

Key words: inflammatory bowel disease, liver diseases, ulcerative colitis, crohn's disease, primary sclerosing cholangitis, drug induced liver injury, hepatitis $B$

Received: August 26, 2017; Accepted: September 18, 2017; Published: September 21,2017 
hepatitis, substance abuse and alcohol abuse. Further, an etiology-based approach to an abnormal liver test should examine the pattern of liver injury, whether cholestatic or hepatocellular, and clinicians should inquire about the patient's use of over-the-counter medications, NSAIDs, and any other drugs.

In a cholestatic pattern of liver injury, the elevation of alkaline phosphatase is out of proportion to the transaminases. This pattern of injury includes primary sclerosing cholangitis (PSC), drug-related liver injury from drugs used to manage IBD or others, cholestasis, autoimmune hepatitis, PSC overlap syndrome, granulomatous hepatitis, hepatic abscess or, rarely, hepatic amyloidosis.

A hepatocellular pattern of liver injury presents with an elevated transaminitis out of proportion to alkaline phosphatase. This too can occur through drug related liver injury, stemming either from drugs used for the management of IBD or others, NAFLD (with ALT > AST), autoimmune hepatitis, as well as PSC overlap syndrome, viral hepatitis or autoimmune hepatitis.

Below we discuss our findings from the literature on the a few of the overarching types of hepatobiliary complications associated with IBD, possible subtypes, and evidence-based recommendations for clinical work-up and therapeutic approaches.

\section{Non-alcoholic Fatty Liver Disease (NAFLD)}

Physicians have long been trained to recognize the association of fatty liver with IBD. However, only with the past decade's growing concerns about obesity has fatty liver's astounding prevalence of $50 \%$ to $60 \%$ of patients with IBD, been recognized. Globally, fatty liver is both on the rise and well on its way to be the leading cause of liver transplant, given that excessive fat deposition and its associated oxidative stress, in turn leads to fibrosis, cirrhosis and even liver cancer. Nevertheless, NAFLD has one important, positive attribute: with early recognition and such decisive interventions as a $10 \%$ reduction in body weight, exercise and adherence to a balanced diet, reversal is possible. That said, fatty liver is multi-factorial and seen in non-obese, as well as the obese, populations. Hence, an extensive workup is required to ascertain the true etiology of fatty liver in specific patients. During this workup, it important to avoid assumptions about any specific etiologies, including its association with IBD [21,22].

Hepatic steatosis in IBD was first reported on an autopsy finding by C. H. Thomas in 1873; it was described as "a much enlarged fatty liver" in a young patient with "ulceration of the colon" [23]. Numerous case series, including studies well before the current obesity epidemic, depicted steatosis in patients with IBD. However, the obesity epidemic, coupled with effective pharmacotherapy for the management of IBD, has altered the phenotype of a malnourished, under-weight IBD patient to one identified as having NAFLD. NAFLD, moreover, has an increasing incidence and prevalence in the general population, and it is likely to be more prevalent in future in patients with IBD.

The etiology of NAFLD in IBD is poorly understood, but considered to be multi-factorial and influence by such factors as age, gender, alcohol use, presence of metabolic syndrome (insulin resistance), IBD disease activity, duration of disease, gut dysbiosis, history of IBD related surgical intervention, medications used (corticosteroids, antiTNF agents) and parenteral nutrition playing a role. The prevalence of NAFLD in IBD populations ranges from $6.2 \%$ to $40 \%$ [24-30], with the obvious discrepancy observed in this range attributed to varied definitions for describing NALFD, as well as to the different tools used for diagnosis. Ultrasonography for the diagnosis of NAFLD has a sensitivity and specificity of $85 \%$ (95\% CI: $79.5-88.9 \%)$ and $94 \%(95 \%$ CI: 87.2-97\%), respectively [31].

NAFLD is the leading cause of elevated transaminases (ALT $>$ AST, except in cirrhosis). Limited data exists on liver fibrosis and IBD, but they are respectively reported to be between $6.4 \%$ and 10 [32]. The degree of steatosis, a reflection of IBD disease activity, may be reversed with the treatment of IBD [25]. The prevalence of metabolic syndrome in IBD patients has geographical variation. Nagahori et al. in 2010 in J Gastroent reported that, in Japan, its prevalence was $18.6 \%$, and thus comparable with the general population. However, a 2013 study conducted by Sourianarayanane et al. in J Crohn's colitis in 2013 demonstrated a lower prevalence of metabolic syndrome in the IBD population as compared to the general American population.

Dysbiosis with alteration of gut microbiota has been associated with IBD disease activity and NAFLD [33,34], with the duration of IBD identified as an independent risk factor for NAFLD [30]. The topic on IBD related medications and liver toxicity including NAFLD has been covered later in this review article. NAFLD can lead to cirrhosis and its complications, yielding increased morbidity and mortality with coexisting IBD.

At present no specific guidelines exist for screening or assessing patients with IBD for NAFLD. However, patients are usually asymptomatic and may present with hepatomegaly. Biochemical and histological improvements in NAFLD patients have been achieved with $>7 \%$ weight loss [35]. Obese patients with CD may have increased anoperineal disease, require earlier surgical intervention and experience greater surgical complications than their non-obese counterparts [36-38]. Elevated liver enzymes with NAFLD can limit the use of Azathioprine and Methotrexate. Patients should be advised to monitor for excessive weight and to maintain healthy dietary and exercise habits.

\section{Primary Sclerosing Cholangitis (PSC)}

PSC is a chronic progressive cholestatic liver disease characterized by gradual inflammation and fibrosis of intrahepatic and/or extrahepatic bile ducts leading to chronic cholestasis and elevated alkaline phosphatase. PSC is the most specific hepatobiliary manifestation of IBD $[1,39,40]$. It is likely the most well-known condition almost all physicians associate with IBD. It may have a characteristic presentation while its diagnosis requires a high index of suspicion. Recurrent cholangitis is one of the most serious complications associated with PSC. Its management involves the use of ursodeoxycholic acid aimed to reduce the progression of PSC; while a liver transplant remains the sole long term treatment hope. A host of other medications including anti-inflammatory agents or biologics, none have shown to alter the natural course of progression of the disease. PSC's incidence ranges from 0 to 1.3 per 100,000 person/year, its prevalence is 0 to 16.2 per 100,000 people [41], and it usually affects young and middle aged patients, especially those with underlying IBD $[39,42]$, with median age of onset between 30 and 40 years. From $0.4 \%$ to $7.5 \%$ of patients with IBD develop PSC [1,42]; however, among patients with an established PSC diagnosis, $70 \%$ to $80 \%$ have UC and $15 \%$ to $20 \%$ have CD $[43,44]$. Of note, IBD is associated with poorer outcomes in patients with PSC with increased risk for malignant complications and hence requirement for liver transplantation [45]. The natural course of PSC, though varied, is usually progressive and can lead to liver cirrhosis and failure $[39,46]$.

\section{PSC: Etiology and pathogenesis}

PSC's exact etiology is unknown. Genetic susceptibility, autoimmune mechanism, intestinal dysbiosis with toxin production 
from the gut microbiota, chronic portal bacteremia, unrecognized viral infections, as well as abnormal metabolism, transport and immunoregulation of bile acids have all been proposed [47-49]. However, multiple HLA haplotypes have been associated with PSC [50], and at the genome level, about 16 risk loci, accounting for $7.3 \%$ of overall liability [51], have been identified for PSC. These risk loci for PSC overlap with risk loci for UC and/or CD [52,53].

The pathogenesis of pathogenesis of PSC has been proposed to arise through increased intestinal permeability during bacterial translocation, as well as activation of innate immune response [54,55]. This view suggests that the ectopic aberrant expression of mucosal address in cell adhesion to molecule 1, expressed in the liver and usually in PSC and other liver inflammatory states, along with those T-helper cells responsible for liver fibrosis, are primed in the intestine, circulate via entero-hepatic circulation and linger as memory cells, triggering in a portal inflammation that results in biliary destruction [56-58].

\section{PSC-diagnosis}

PSC is an uncommon medical condition, with as many as half the patients affected by it asymptomatic. A diagnosis of PSC must be considered when cholestasis occurs, especially in the setting of colitis. Patients with a history of colitis, recurrent cholangitis, and symptoms of pruritus and jaundice may be more likely to have sclerosing cholangitis. Note that patients may have ascending cholangitis characterized by fevers, chills, or both, right upper quadrant pain, and jaundice. Physical findings may be nonspecific; however, icterus, excoriation, or hepatosplenomegaly, especially in a male, may suggest the diagnosis [59]. Presenting symptoms for PSC are often fatigue (75\%), pruritus (50\%), weight loss (40\%), and fever (35\%) [54,59]. Mean survival after diagnosis of PSC is 10-12 years [39,60-62], with survival much shorter for patients who are symptomatic at the time of diagnosis.

Laboratory testing for PSC will reveal a cholestatic pattern, with elevated alkaline phosphatase and mild elevations in transaminases, hypergammaglobulinemia and IgM. A low albumin is indicative of active IBD and poor prognosis [63]. To establish the diagnosis of PSC, intrahepatic and/or extrahepatic strictures must be demonstrated, either by magnetic resonance cholangiopancreatography (MRCP), endoscopic retrograde cholangiopancreatography (ERCP), or percutaneous transhepatic cholangiography [63].

MRCP provides the test of choice for PSC, as it is readily available, less invasive and a cost effective option for the initial diagnosis; however, MRCP does not provide access to the biliary tree for tissue diagnosis or therapeutic manipulation [64,65]. Also, MRCP can miss early PSC changes and large duct involvement for which an ERCP is more helpful [63]. ERCP allows for an easy identification of fibrotic annular strictures that alternate with normal or dilated segments to produce the characteristic beaded pattern of the biliary tree. It also provides histologic/cytological sampling and therapeutic maneuvers.

A liver biopsy is not always indicated. We should, however, obtain a liver biopsy if the MRCP and ERCP are non-diagnostic, as well as a cholestatic biochemical profile to rule out small duct PSC or, if we suspect an overlap syndrome of PSC, with autoimmune hepatitis [63]. The classical biopsy finding for PSC includes the fibrous obliteration of the small duct, with periductal concentric fibrosis in an "onion skin" fashion. However, periductal fibrosis, seen in secondary forms of sclerosing cholangitis [66,67], is not pathognomic for PSC, and is seldom seen.

\section{Management of PSC}

With no current medical management available to decrease PSC progression, the currently available aim is to halt its progression with UDCA (Ursodeoxycholic acid) and to manage its complications. UDCA enhances hepatobiliary secretion and protects cholangiocytes and hepatocytes from apoptosis $[68,69]$.

Trials suggests a dose of 13 to $15 \mathrm{mg} / \mathrm{kg} /$ day of UDCA as appropriate [70,71]. Higher doses of UCDA (20-30 mg/kg/day) have been shown to be detrimental, rather than to have any substantial clinical benefit [7276]. UCDA does not improve liver histology or liver transplant free survival, nor does it prevent the development of cholangiocarcinoma, colonic adenomas, colon cancer or incidence of death [73,77-79]. Corticosteroids have not been proven effective either as single agents or when used with colchicine or ursodeoxycholic acid [80], nor have methotrexate, colchicine, pentoxifylline, etanercept, or mycophenolate mofetil proved useful in PSC [81-86]. Preliminary studies suggest that selected antibiotics may be beneficial but evidence for their routine clinical use is lacking [87-89].

Pruritus in PSC is common; its initial management consists of cholestyramine or colespitol (bile acid sequestrants). Where prurities is refractory to bile acid sequestrants, patients should be treated with either Rifaximin (150-300 mg twice daily), Naltrexone (50 mg daily) or Sertraline (75-100 mg daily) [90].

Advice against alcohol consumption, smoking and marijuana use. A review of hepatitis A and B status (to assess any exposure) and recommendation of vaccinations is vital. Warn patients to avoid highrisk behaviors for hepatitis $\mathrm{C}$, such as intravenous drug use and sexual promiscuity.

Patients with decompensated advanced liver disease, hepatocellular carcinoma or refractory bacterial cholangitis should be evaluated for liver transplant. The outcome from liver transplantation for PSC is substantially better than would be predicted from natural history models $[91,92]$. The possibility of recurrent PSC in the transplanted liver exists, however, and may affect graft and patient survival [93-95].

\section{IgG4-associated cholangiopathy (IAC)}

The pathogenesis of IAC is largely unknown. IAC has been described in patients with UC and is a IgG4-related systemic disease causing biliary destruction similar to PSC [96]. Although 9\% to $36 \%$ of patients with PSC may have elevated IgG4; these levels are lower than in patients with IAC $[97,98]$ and hence the tissue diagnosis of IgG4 plasma cell infiltration in the bile duct has greater diagnostic utility $[96,99]$.

\section{Primary biliary cholangitis (PBC)}

Several case reports of PBC in UC have been published [100,101]. Though PBC and UC share some common HLA haplotypes [101,102], the prevalence of $\mathrm{PBC}$ in UC patients have been reported to occur only by chance [103]. These IBD patients with PBC were generally young with a male preponderance. Also, the UC was mild with limited colitis $[100,101]$.

\section{Medication associated liver injury in IBD}

Most drugs used for the suppression of IBD activity has potential for liver toxicity; though serious complications are relatively low $[24,104]$. The mechanism of hepatoxicity for these drugs is complex and ranges from immune mediated, metabolic, direct toxic effects to induction or worsening of intrinsic liver disease. The laboratory finding of hepatocellular versus cholestatic pattern of injury helps clinician's decipher the etiology of the injury (Table 1). 
Table 1. Medications and hepatotoxicity

\begin{tabular}{|l|l|l|}
\hline Medication & Mechanism of injury & Liver toxicity \\
\hline Corticosteroids & Oxidative hepatotoxicity & $\begin{array}{l}\text { Worsening of NASH, steatosis } \\
\text { Chronic hepatitis B reactivation }\end{array}$ \\
\hline Aminosalicylates & $\begin{array}{l}\text { 1. Hypersensitivity } \\
\text { 2.5-ASA components toxicity }\end{array}$ & $\begin{array}{l}\text { Drug induced hepatitis } \\
\text { Cholestasis } \\
\text { Granulomatous hepatitis } \\
\text { Drug induced pancreatitis }\end{array}$ \\
\hline Thiopurines & $\begin{array}{l}\text { 1. Direct toxicity from } \\
\text { intracellular accumulation } \\
\text { 2. Damage to the vascular } \\
\text { endothelium }\end{array}$ & $\begin{array}{l}\text { Asymptomatic transaminitis } \\
\text { Drug induced hepatitis } \\
\text { cholestasis } \\
\text { Nodular regenerative hyperplasia } \\
\text { Drug induced pancreatitis }\end{array}$ \\
\hline Methotrexate & $\begin{array}{l}\text { Is stored in the liver as a } \\
\text { polyglutamate metabolite which } \\
\text { is hepatotoxic with long term } \\
\text { use } 105\end{array}$ & $\begin{array}{l}\text { Asymptomatic transaminitis } \\
\text { Steatosis } \\
\text { Fibrosis } \\
\text { Drug induced pancreatitis }\end{array}$ \\
\hline $\begin{array}{l}\text { Infliximab and } \\
\text { Adalimumab } \\
\text { ( Monoclonal } \\
\text { antibodies against } \\
\text { TNF } \alpha \text { ) }\end{array}$ & $\begin{array}{l}\text { Interfere with the activity of } \\
\text { TNF } \alpha-\text { leads to precipitation } \\
\text { of "denovo autoimmune } \\
\text { hepatitis", cholestasis and direct } \\
\text { hepatocellular necrosis 13,106 }\end{array}$ & $\begin{array}{l}\text { Chronic hepatitis B reactivation } \\
\text { or hepatitis C reactivation } \\
\text { Cholestasis }\end{array}$ \\
\hline $\begin{array}{l}\text { Combination of } \\
\text { anti-TNF and } \\
\text { immunosuppressive } \\
\text { therapy }\end{array}$ & $\begin{array}{l}\text { Interfere with the activity of } \\
\text { TNF } \alpha-\text { leads to precipitation } \\
\text { of "denovo autoimmune } \\
\text { hepatitis", cholestasis and direct } \\
\text { hepatocellular necrosis } 13,106\end{array}$ & Hepatosplenic T-cell lymphoma \\
\hline
\end{tabular}

\section{Aminosalicylates: Sulfasalazine and mesalamine}

The mechanism of the anti-inflammatory properties of Aminosalicylates are not entirely understood but is attributed to inhibition of both prostaglandins and leukotrienes. Sulfasalazine is largely replaced (due to adverse effects) by Mesalamine and is indicated in the induction and maintenance of mild to moderate Ulcerative Colitis. The mechanism of injury is by the following [105,106]:

Hypersensitivity to Sulfasalazine: This can in rare cases lead to acute liver failure presenting with fever, tender hepatomegaly, lymphadenopathy, transaminitis and hyperbilirubinemia [107,108].

Directly toxicity from the 5-ASA component: This can lead to both acute or chronic hepatitis and has been shown to occur mostly between 6 days to 1 year of starting the drug

Both 5-ASA and Sulfasalazine are equally responsible for the number of cases of drug induced hepatitis from Aminosalicylates [109113]. Studies have reported liver enzyme abnormalities in up to $2 \%$ of patients on Mesalamine [114]. Most of these abnormalities have no clinical significance. The use of Mesalamine and 5-ASA are considered low risk as an etiology for the development of toxic hepatitis (3.2 and 6 cases per million prescriptions for Mesalamine and sulfasalazine respectively) [115] and hence close liver enzyme monitoring is not deemed necessary. Cholestasis, granulomatous hepatitis and drug induced pancreatitis have also been reported in patients on Aminosalicylates.

\section{Corticosteroids}

Corticosteroids when used for a short duration for induction therapy causes minimal liver injury. When used at higher doses for extended periods corticosteroids can enhance NASH and oxidative hepatotoxicity in high risk patients with obesity, insulin resistance, uncontrolled diabetes and hypertriglyceridemia [116].

\section{Thiopurines}

Thiopurines are immunomodulators indicated for the maintenance of clinical remission in CD and UC. Azathioprine (the pro-drug) and 6 mercaptopurine (6-MP) convert to the metabolite $6-\mathrm{MMP}$ (6-methylmercaptopurine) and 6-TG (6-Thioguanine); the levels of which relates to the therapeutic efficacy and the drug [117] (Figure 1).

6-MMP levels relates to therapeutic efficacy and in very high levels relates to liver toxicity. 6-TG levels also relates to therapeutic efficacy and in high levels relates to bone marrow toxicity.

TPMT Genotype is measure before initiating AZA or 6-MP to reduce hepatic toxicity. Those with homozygous mutant alleles should not receive azathioprine or 6-MP. Those with normal/heterozygousshould be started on low dose and then increase the dose every 2-4 weeks. Routine liver enzyme monitoring is advised. The medication can be continued with mild abnormalities without clinical symptoms; but should be discontinued when patient develops jaundice or abnormalities persists despite lowering the dose of Azathioprine or 6-MP [118].

The measurement of the TPMT enzyme activity (phenotype) helps guide the Azathioprine or 6-MP dose and detect possible non-adherence. Undetectable TPMT levels may be due to altered metabolism or nonadherence. High TPMT-levels may suggest toxicity (Table 2).

Hepatotoxicity secondary to the use of Thiopurines ranges from $3 \%$ (in retrospective trials) to $10 \%$ (in prospective trials) [119]. The occurrence of hepatotoxicity increases with concomitant use of corticosteroids [119]. Pancreatitis and veno-occlusive disease caused by Thiopurines is an example of the dose independent side event while hepatotoxicity is dose dependent (and hence is reversible with discontinuation).

The mechanism of injury of Thiopurines is believed to be by:

1. Intracellular accumulation of 6-MMP and 6-TG: which is a direct result of reduced TPMT enzymatic activity

2. Damage to the sinusoidal vascular endothelium: It's rare and patients present with veno-occlusive disease and NRH (nodular regenerative hyperplasia). These patients usually present with noncirrhotic portal hypertension.

\section{Methotrexate}

Methotrexate impairs DNA synthesis via inhibition of dihydrofolate reductase and also blocks T cell activation and expression

Table 2. TPMT: Its genotype and phenotype and its significance

\begin{tabular}{|l|l|l|l|}
\hline $\begin{array}{l}\text { TPMT } \\
\text { Genotype }\end{array}$ & $\begin{array}{l}\text { TPMT } \\
\text { Phenotype }\end{array}$ & \% population & Significance \\
\hline wild type & $\begin{array}{l}\text { Normal/high } \\
\text { enzyme activity }\end{array}$ & $89 \%$ & 6-MP works well \\
\hline $\begin{array}{l}\text { Heterozygous } \\
\text { mutations }\end{array}$ & $\begin{array}{l}\text { low TPMT } \\
\text { enzyme activity }\end{array}$ & $11 \%$ & May require higher doses of 6-MP \\
\hline $\begin{array}{l}\text { Homozygous } \\
\text { mutations }\end{array}$ & negligible activity & $0.3 \%$ & $\begin{array}{l}\text { 6-MP is ineffective } \\
\text { Also causes 6-MP to be } \\
\text { preferentially metabolized to } \\
\text { produce higher levels of 6-TG }\end{array}$ \\
\hline
\end{tabular}

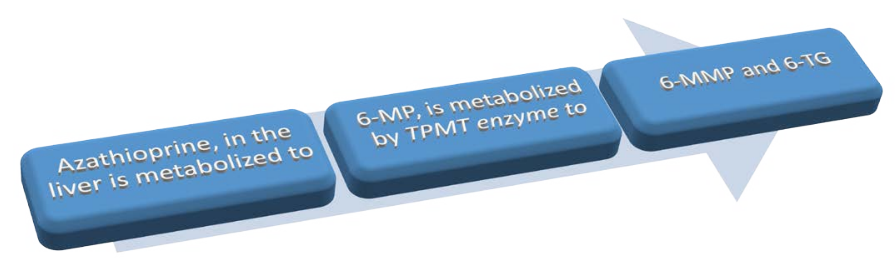

Figure 1. Thiopurine metabolism 
of intercellular adhesion molecules [120]. It is indicated for use in the maintenance of the clinical remission of steroid dependent CD patients [121]. A meta-analysis of the use of methotrexate in IBD patients published in $I B D$ in 2012 revealed elevation of transaminases (was seen in $10.5 \%$ of the patients) to be usually $<2$ fold the upper limit of normal. This transaminitis reduced without any intervention with only $2.68 \%$ requiring discontinuation [9].

The careful selection of patients (avoidance of use of Methotrexate in patients with obesity, alcohol related health problems, diabetes) and close monitoring combined with use of folic acid or folinic acid has reduced the incidence of hepatotoxicity associated with Methotrexate $[9,122]$. Methotrexate should be discontinued if the patient develops fibrosis or cirrhosis [123].

Earlier when the cumulative dose of methotrexate exceeded 1.5 grams a liver biopsy was warranted [124]; but this is no longer the case. Recent guidelines suggests closer monitoring of transaminases and albumin every 4-8 weeks and later every 8-12 weeks upon stabilization of the dose. A liver biopsy should be performed only if 6 out of the 12 tests within a year is abnormal [125]. The future role of fibroscan in monitoring of patients on Methotrexate is yet to be ascertained [123].

\section{Biologic agents}

Infliximab and Adalimumab are monoclonal antibodies directed against TNFa (which usually plays a role in hepatic regeneration) and is indicated for the induction and remission of steroid resistant and steroid dependent CD and UC [126,127]. Upon withdrawal of viral suppression as a result of immunosuppression with biologics; patients with chronic hepatitis $\mathrm{B}$ and hepatitis $\mathrm{C}$ are prone for reactivation with viral replication. The mechanism of injury with use of biologics is detailed in the table above. HSTCL (Hepatosplenic T-cell lymphoma) is a rare and fatal complication (seen mostly in young males) described with use of combination of anti-TNF and immunosuppressive therapy $[12,128,129]$.

Natalizumab is a a4-integrin monoclonal antibody was used for the management of IBD (in Europe) and has been associated with severe liver injury, liver failure and progressive multifocal leukoencephalopathy (PML) [130,131].

Vedolizumab is a gut specific anti-integrin therapeutic antibody. Evidence collected from pre-licensure controlled trials reveal $<2 \%$ of patients with Vedolizumab demonstrating $>5$ times the upper limit of normal ALT elevation; which was similar to the placebo group [132]. No cases of significant liver toxicity has been reported till date.

\section{Hepatitis B and IBD}

Hepatitis B is a DNA virus that permanently leaves its genetic imprint, the ccc DNA (covalently closed circular DNA), which is embedded in the nucleus of the hepatocytes. The ccc DNA serves as a persistent viral reservoir and is responsible for hepatitis $\mathrm{B}$ re-activation following host immunosuppression. Nucleos(t)ides such as Tenofovir or Entecavir achieve sufficient viral suppression via blocking HBV DNA synthesis in the hepatocyte cytoplasm, but do not affect the ccc DNA in the nucleus of the hepatocytes. Immunosuppressive agents used for the management of IBD can result in the cessation of viral suppression resulting in HBV reactivation. This ccc DNA serves as the template for HBV transcription and subsequent replication.

The HBV reactivation is of various types as detailed below (Table 3 ).

Various recommendations exists for the screening of HBV reactivation especially before initiation of immunosuppressive
Table 3. Types of HBV reactivation

\begin{tabular}{|c|c|c|c|c|}
$\begin{array}{c}\text { HBV reactivation } \\
\text { types }\end{array}$ & HBV DNA & ALT & $\begin{array}{c}\text { Symptoms of } \\
\text { liver injury: } \\
\text { jaundice/fatigue }\end{array}$ & $\begin{array}{c}\text { Liver failure: } \\
\text { Coagulopathy, hepatic } \\
\text { encephalopathy, ascites }\end{array}$ \\
\hline Silent & detectable & Normal & No & No \\
\hline Mild & detectable & High & No & No \\
\hline Moderate & detectable & High & Yes & No \\
\hline Severe & detectable & High & Yes & Yes \\
\hline
\end{tabular}

medications. The AASLD recommends screening of hepatitis B reactivation with $\mathrm{HBsAg}$ and anti-HBC while the USPSTF recommends only HBsAg. Before initiating any patients on immunosuppressive agents we have to perform a risk stratification for the reactivation of HBV infection. This risk stratification is based on the presence of hepatitis B surface antigen and the medication been used.

HBV reactivation is an underappreciated challenge and we should screen everyone as all patients face the risk of reactivation. It is not uncommon, can be lethal and is preventable. All HBsAg positive should be treated. For patients that are HBsAg negative with anti-HBc positive indicating a past infection we need to determine they risk status and start anti-virals accordingly. Tenofovir or Entecavir is used for at least the duration of the immunosuppression. Further studies need to be carried out to ascertain the cost of routine screening and monitoring of laboratory parameters in the diagnosis and follow up of hepatitis $B$ reactivation.

\section{Hepatitis C and IBD}

Contrary to a study by Hou et al. [134] it has been reported that the prevalence of hepatitis $\mathrm{C}$ infection in IBD sub-group is comparable to the general population $[135,136]$. Corticosteroids are considered to flare hepatitis $\mathrm{C}$ viral replication especially after a liver transplant but no prospective studies exists. Also Azathioprine, Methotrexate, cyclosporine and mycophenolate mofetil has been shown to be safe for use in transplanted patients without any hepatitis $C$ reactivation [137139]. Thus, immunosuppressive agents used in IBD do not result in HCV reactivation.

Till the advent of directly acting anti-virals for the management of hepatitis $C$ the IBD subgroup with hepatitis $C$ infection were always excluded and hence not many trials exists to decipher whether hepatitis $\mathrm{C}$ medications affected the natural course of IBD. Several case reports of use of interferon in patients with IBD and hepatitis C concluded interferon not to adversely affect the IBD course [14-144]. Zein et al. demonstrated improved SVR (sustained virological response) rates when etanercept (an anti-TNF agent) was used in conjunction with interferon and ribavirin. This shows that anti-TNF agents are safe to use in IBD patients with hepatitis C infection [145]. Thus, anti-virals for hepatitis $\mathrm{C}$ does not have any adverse outcome on the IBD course.

\section{Granulomatous hepatitis}

Granulomatous hepatitis is a rare complication of Crohn disease. It's usually benign and not progressive. The patients are mostly asymptomatic; but may have symptoms secondary to Crohn's disease. The main laboratory abnormality is that of an elevated alkaline phosphate. Some have a mild degree of transaminitis while hyperbilirubinemia is rare. Granulomatous hepatitis and its association with the use of Sulfasalazine for the management of Crohn's disease has also been well documented [104]. Ultrasound and CT scan is usually normal while lesions $>5 \mathrm{~mm}$ are identified on an MRI. A complete workup for any hepatic granuloma depends on the positive history and exam findings while a liver biopsy for its diagnosis 
is not indicated. When a biopsy is performed (for other indications); a non caseating granuloma with epithelioid cells, giant cells and lymphocytes. Granulomatous hepatitis secondary to inflammatory bowel disease rarely requires treatment (which includes corticosteroids and immunosuppressive drugs) (Table 4).

\section{Secondary Amyloidosis}

Secondary or reactive amyloidosis in IBD is associated with chronic inflammation of the gut leading to extracellular (vasculature and sinusoids) amyloid deposition in the liver. The prevalence of amyloidosis in IBD has been estimated to be around 3\% [146]. The incidence is higher in male individuals with colonic involvement and more common in Crohn's disease when compared to Ulcerative colitis $[146,147]$. Patients present with asymptomatic hepatomegaly and rarely the diagnosis of hepatic amyloidosis precedes that of IBD [146]. Suppression of gut inflammation in Crohn's disease reduces the oxidative burden thereby reducing precursors of amyloid fibrils and progression of hepatic amyloidosis [147,148]. Though medical management has limited success; colchicine, budesonide and infliximab been tried with varied results [149-151].

\section{Cholelithiasis}

The incidence of cholelithiasis in CD is doubled when compared to IBD-free controls and has been reported to be between $13 \%$ and $34 \%$ $[6,152]$. UC (which does not involve the small bowel) is not considered a risk factor for cholelithiasis. Patients with ileo-colonic $\mathrm{CD}$ are at increased risk of cholelithiasis when compared to CD patients with only the ileal involvement [153-155]. Past history of intestinal resections and the number of resections have also been implicated as risk for the development of cholelithiasis [26,152-155]. Ileal involvement (either resection or inflammation) with decreased bile salt absorption leading to lithogenic super saturated bile is considered the main mechanism for the development of cholelithiasis in this sub-group [156,157]. Also, patients undergoing ileoanal anastomosis have been identified to have increased gallstone cholesterol concentration leading to cholelithiasis [158].

\section{Portal vein thrombosis}

This is a relatively rare yet significant complication observed in patients with IBD secondary to a consequence of an inflammatory hypercoagulable state [159-161]. $1 \%$ to $2 \%$ of patients with IBD have been found to have thrombosis of the portal and the mesenteric veins [162]. IBD patients are hypercoagulable with elevated platelets, fibrinogen, factor V and VIII levels and reduced anti-thrombin III levels $[163,164]$. Portal vein thrombosis is most likely to occur in patients with UC undergoing restorative protocolectomy [165168]. Landman et al. published their incidental finding of $40 \%$ of the patients with inactive IBD with portomesenteric vein thrombosis [169]. Some single center studies have elucidated the course of portal vein thrombosis to be benign [170,171]. Patients with IBD do not have a higher incidence of genetic clotting abnormalities but may develop acquired prothrombotic disorder secondary to disease activity $[172,173]$. A six month course of anticoagulation has been instituted at

Table 4. Medications associated with granulomatous liver lesions

\begin{tabular}{|c|c|c|}
\hline & & \\
\hline Allopurinol & Gold & Nitrofurantoin \\
\hline BCG & Hydralazine & Phenytoin \\
\hline Carbamazepine & Interferon & Procainamide \\
\hline Chlorpropramide & Mebendazole & Quinidine \\
\hline Diltiazem & Methyldopa & Sulfa drugs \\
\hline
\end{tabular}

various centers. However lifelong systemic anticoagulation is indicated in known congenital hypercoagulable states [162].

\section{Budd Chiari Syndrome}

Several case reports of IBD patients with Budd Chiari syndrome has been published $[174,175]$. Due to the hypercoagulable state spontaneous thrombolic embolism can occur; the risk of which is eight times higher during an acute flare [164]. Also, patients during any perioperative period are considered to be at increased risk for the development of thromboembolism.

\section{Hepatic abscess}

Liver abscess is a rare complication of CD that has been elucidated in case reports and cohort studies [176,177]. Hepatic abscess could be an initial manifestation of CD [178,179]. A typical presentation is that of a young patient with fever, abdominal pain, jaundice, diarrhea or hepatomegaly. Presence of abdominal abscess, malnutrition, fistulizing $\mathrm{CD}$ and corticosteroid therapy are known risk factors for the development of hepatic abscesses [179]. The mechanism of the formation of the abscess is not fully understood and is thought to be either secondary to the extension of the pre-existing abdominal abscess, portal pyemia with seeding of the hepatic parenchyma or due to increased intestinal mucosal permeability with the involvement of the tight junctions. Management of hepatic abscess includes surgical drainage [180] and lowering of the IBD activity.

\section{Pancreatitis}

Pancreatitis is rare and usually results in patients with IBD due to ampullary CD, cholelithiasis, PSC or medications (including 6-mercaptopurine and Azathioprine). In a study the use of Azathioprine and 6-mercaptopurine in IBD population resulted in increased risk of pancreatitis when compared to patients treated with these drugs for other causes [181].

Autoimmune pancreatitis (AIP) resembles IBD-associated pancreatitis $[182,183]$. When compared to the general population the prevalence of IBD in patients with AIP was 10 -fold, hence indicating that AIP could be contributing to the clinical finding of IBD-associated pancreatitis $[184,185]$. Data from a single prospective study of IBD patients with pancreatitis with high serum IgG4 is available and this needs to be further incorporated and validated in future studies.

\section{IBD and liver transplantation}

Development of De novo IBD after liver transplantation is infrequent; and has been described in various case series [186-189]. The exact etiology is unknown; though a damage-associated or pathogenassociated molecular pattern has been implicated [188]. Presence of a positive CMV donor with a negative recipient $[189,190]$ and use of Tacrolimus post-liver transplant [191] has been identified as risk factors for the development of de novo IBD. It is believed that CMV and Tacrolimus can affect the mucosal immune system (via altering the epithelial barrier system [189] or reducing the interleukin-2 dependent generation of regulatory $T$ cells $[192,193]$ respectively) increasing IBD activity. The diagnosis and management is often challenging. Steroids, Azathioprine and anti-TNF therapy have a good therapeutic response [189].

Conflicting reports of IBD activity have been published regarding the impact of a liver transplant on patients with preexisting IBD [192196]. Risk factors for worsening of preexisting IBD after liver transplant includes active bowel inflammation at the time of transplantation [193], short interval between diagnosis of IBD and transplant [193], 
cigarette smoking [197], Clostridium difficile infection [198] and use of Tacrolimus after transplant $[191,193,199,200]$. The use of steroid or immunosuppressive agents prior to transplant does not predict post-transplant IBD activity [194,195]. Steroids, Azathioprine and Cyclosporine should be preferred in these subgroup of patients [94,193,199-201]. The therapeutic response and outcome is usually poor when compared to the de novo IBD patients; requiring colectomy for refractory bowel disease [197,199,200]. Conflicting evidence suggesting for and against the association of use of immunosuppressive agents and CRC have been published [202,203].

PSC patients with IBD who have undergone a liver transplantation usually present with prolonged subclinical IBD activity and hence may underestimate the colorectal cancer (CRC) risk [204]. However, there are at increased risk for CRC (even when adjusted for the diagnosis of PSC and IBD in similar populations) $[205,206]$ and should be monitored with annual colonoscopy [199,207].

\section{Conclusion}

Hepatobiliary manifestations associated with IBD are common and underdiagnosed. In conclusion, physicians managing IBD patients should be critically aware of these manifestations. Also, important to note is that these disorders may present differently and at times be asymptomatic. It is possible to improve the management and outcome with careful anticipation, screening and identifying complications early. Complex cases require a multidisciplinary approach including gastroenterology, general surgery, colorectal surgery and transplant surgery.

\section{Acknowledgments}

We thank Jo Anne Fordham, for her assistance in the critical review of the manuscript

\section{References}

1. Bernstein CN, Blanchard JF, Rawsthorne P, Yu N (2001) The prevalence of extraintestinal diseases in inflammatory bowel disease: a population-based study. $\mathrm{Am} \mathrm{J}$ Gastroenterol 96: 1116-1122. [Crossref]

2. Ricart E, Panaccione R, Loftus EV Jr., Tremaine WJ, Harmsen WS, et al. (2004) Autoimmune disorders and extraintestinal manifestations in first-degree familial and sporadic inflammatory bowel disease: a case-control study. Inflamm Bowel Dis 10: 207214. [Crossref]

3. Bernstein CN, Wajda A, Blanchard JF (2005) The clustering of other chronic inflammatory diseases in inflammatory bowel disease: a population-based study. Gastroenterology 129: 827-836. [Crossref]

4. Mendoza JL, Lana R, Taxonera C, Alba C, Izquierdo S, et al. (2005) [Extraintestinal manifestations in inflammatory bowel disease: differences between Crohn's disease and ulcerative colitis]. Med Clin (Barc) 125: 297-300. [Crossref]

5. Greenstein AJ, Janowitz HD, Sachar DB (1976) The extra-intestinal complications of Crohn's disease and ulcerative colitis: a study of 700 patients. Medicine (Baltimore) 55: 401-412. [Crossref]

6. Navaneethan U, Shen B (2010) Hepatopancreatobiliary manifestations and complications associated with inflammatory bowel disease. Inflamm Bowel Dis 16: 1598-1619. [Crossref]

7. Peyrin-Biroulet L, Loftus EV Jr, Colombel JF, Sandborn WJ (2010) The natural history of adult Crohn's disease in population-based cohorts. Am J Gastroenterol 105: 289-297. [CrossRef]

8. Uko V, Thangada S, Radhakrishnan K (2010) Liver disorders in inflammatory bowel disease. Gastroenterol Res Pract 2012: 642923. [Crossref]

9. Khan N, Abbas AM, Whang N, Balart LA, Bazzano LA, et al. (2012) Incidence of liver toxicity in inflammatory bowel disease patients treated with methotrexate: a metaanalysis of clinical trials. Inflamm Bowel Dis 18: 359-367. [Crossref]

10. Cassaday RD, Malik JT, Chang JE (2011) Regression of Hodgkin lymphoma after discontinuation of a tumor necrosis factor inhibitor for Crohn's disease: a case report and review of the literature. Clin Lymphoma Myeloma Leuk 11: 289-292. [Crossref]
11. Morisco F, Castiglione F, Rispo A, Stroffolini T, Vitale R, et al. (2011) Hepatitis B virus infection and immunosuppressive therapy in patients with inflammatory bowel disease. Dig Liver Dis 43: S40-48. [Crossref]

12. Thai A, Prindiville T (2010) Hepatosplenic T-cell lymphoma and inflammatory bowel disease. J Crohns Colitis 4: 511-522. [CrossRef]

13. Miehsler W, Novacek G, Wenzl H, Vogelsang H, Knoflach P, et al. (2010) A decade of infliximab: The Austrian evidence based consensus on the safe use of infliximab in inflammatory bowel disease. J Crohns Colitis 4: 221-256. [Crossref]

14. Kotlyar DS, Osterman MT, Diamond RH, Porter D, Blonski WC, et al. (2011) A systematic review of factors that contribute to hepatosplenic T-cell lymphoma in patients with inflammatory bowel disease. Clin Gastroenterol Hepatol 9: 36-41 e31. [Crossref]

15. Coffin CS, Fraser HF, Panaccione R, Ghosh S (2011) Liver diseases associated with anti-tumor necrosis factor-alpha (TNF-alpha) use for inflammatory bowel disease. Inflamm Bowel Dis 17: 479-484. [Crossref]

16. Flegal KM, Carroll MD, Ogden CL, Curtin LR (2010) Prevalence and trends in obesity among US adults, 1999-2008. JAMA 303: 235-241. [CrossRef]

17. Ogden CL, Carroll MD, Kit BK, Flegal KM (2012) Prevalence of obesity in the United States, 2009-2010. NCHS Data Brief 1-8. [CrossRef]

18. Loftus EV Jr., Sandborn WJ, Lindor KD, Larusso NF (1997) Interactions between chronic liver disease and inflammatory bowel disease. Inflamm Bowel Dis 3: 288-302. [Crossref]

19. Gizard E, Ford AC, Bronowicki JP, Peyrin-Biroulet L (2014) Systematic review: The epidemiology of the hepatobiliary manifestations in patients with inflammatory bowel disease. Aliment Pharmacol Ther 40: 3-15. [Crossref]

20. Pratt DS, Kaplan MM (2000) Evaluation of abnormal liver-enzyme results in asymptomatic patients. $N$ Engl J Med 342: 1266-1271. [Crossref]

21. Kwo PY, Cohen SM, Lim JK (2017) ACG Clinical Guideline: Evaluation of Abnormal Liver Chemistries. Am J Gastroenterol 112: 18-35. [Crossref]

22. Restellini S, Chazouilleres O, Frossard JL (2017) Hepatic manifestations of inflammatory bowel diseases. Liver Int 37: 475-489. [Crossref]

23. Thomas CH (1873) Ulceration of the colon with a much enlarged fatty liver. Trans Pathol Soc Philadelphia 4: 87-88.

24. Gisbert JP, Luna M, Gonzalez-Lama Y, Pousa ID, Velasco M, et al. (2007) Liver injury in inflammatory bowel disease: long-term follow-up study of 786 patients. Inflamm Bowel Dis 13: 1106-1114. [Crossref]

25. Sourianarayanane A, Garg G, Smith TH, Butt MI, McCullough AJ, et al. (2013) Risk factors of non-alcoholic fatty liver disease in patients with inflammatory bowel disease. J Crohns Colitis 7: e279-285. [Crossref]

26. Bargiggia S, Maconi G, Elli M, Molteni P, Ardizzone S, et al. Sonographic prevalence of liver steatosis and biliary tract stones in patients with inflammatory bowel disease: study of 511 subjects at a single center. J Clin Gastroenterol 36: 417-420. [Crossref]

27. de Fazio C, Torgano G, de Franchis R, Meucci G, Arrigoni M, et al. (1992) Detection of liver involvement in inflammatory bowel disease by abdominal ultrasound scan. Int $J$ Clin Lab Res 21: 314-317. [Crossref]

28. Riegler G, D'Inca R, Sturniolo GC, Corrao G, Del Vecchio Blanco C, et al. (1998) Hepatobiliary alterations in patients with inflammatory bowel disease: a multicenter study. Caprilli \& Gruppo Italiano Studio Colon-Retto. Scand J Gastroenterol 33: $93-$ 98. [Crossref]

29. Yamamoto-Furusho JK, Sanchez-Osorio M, Uribe M (2010) Prevalence and factors associated with the presence of abnormal function liver tests in patients with ulcerative colitis. Ann Hepatol 9: 397-401. [Crossref]

30. Bessissow T, Le NH, Rollet K, Afif W, Bitton A, et al.(2016) Incidence and Predictors of Nonalcoholic Fatty Liver Disease by Serum Biomarkers in Patients with Inflammatory Bowel Disease. Inflamm Bowel Dis 22: 1937-1944. [Crossref]

31. Hernaez R, Lazo M, Bonekamp S, Kamel I, Brancati FL, et al. (2011) Diagnostic accuracy and reliability of ultrasonography for the detection of fatty liver: a metaanalysis. Hepatology 54: 1082-1090. [Crossref]

32. Chao CY, Battat R, Al Khoury A, Restellini S, Sebastiani G, et al. (2016) Co-existence of non-alcoholic fatty liver disease and inflammatory bowel disease: A review article. World J Gastroenterol 22: 7727-7734. [Crossref]

33. Liu TC, Stappenbeck TS (2016) Genetics and Pathogenesis of Inflammatory Bowel Disease. Annu Rev Pathol 11: 127-148. [CrossRef] 
34. Fukuda K, Fujita Y (2014) Determination of the discriminant score of intestinal microbiota as a biomarker of disease activity in patients with ulcerative colitis. $B M C$ Gastroenterol 14: 49. [Crossref]

35. Promrat K, Kleiner DE, Niemeier HM, Jackvony E, Kearns M, et al. (2010) Randomized controlled trial testing the effects of weight loss on nonalcoholic steatohepatitis. Hepatology 51: 121-129. [Crossref]

36. Blain A, Cattan S, Beaugerie L, Carbonnel F, Gendre JP, et al. (2002) Crohn's disease clinical course and severity in obese patients. Clin Nutr 21: 51-57. [CrossRef]

37. Hass DJ, Brensinger CM, Lewis JD, Lichtenstein GR (2006) The impact of increased body mass index on the clinical course of Crohn's disease. Clin Gastroenterol Hepatol 4: 482-488. [Crossref]

38. Kiran RP, Remzi FH, Fazio VW, Lavery IC, Church JM, et al. (2008) Complications and functional results after ileoanal pouch formation in obese patients. $J$ Gastrointest Surg 12: 668-674. [Crossref]

39. Wiesner RH, Grambsch PM, Dickson ER, Ludwig J, MacCarty RL, et al. (1989) Primary sclerosing cholangitis: natural history, prognostic factors and survival analysis. Hepatology 10: 430-436. [Crossref]

40. Smith MP, Loe RH (1965) Sclerosing Cholangitis; Review of Recent Case Reports and Associated Diseases and Four New Cases. Am J Surg 110: 239-246. [Crossref]

41. Boonstra K, Beuers U, Ponsioen CY (2012) Epidemiology of primary sclerosing cholangitis and primary biliary cirrhosis: a systematic review. $J$ Hepatol 56: 11811188. [Crossref]

42. Olsson R, Danielsson A, Järnerot G, Lindström E, Lööf L, et al. (1991) Prevalence of primary sclerosing cholangitis in patients with ulcerative colitis. Gastroenterology 100 : 1319-1323. [CrossRef]

43. Boonstra K, Weersma RK, van Erpecum KJ, Rauws EA, Spanier BW, et al. (2013) Population-based epidemiology, malignancy risk, and outcome of primary sclerosing cholangitis. Hepatology 58: 2045-2055. [Crossref]

44. Bergquist A, Lindberg G, Saarinen S, Broome U (2005) Increased prevalence of primary sclerosing cholangitis among first-degree relatives. J Hepatol 42: 252-256. [Crossref]

45. Ngu JH, Gearry RB, Wright AJ, Stedman CA (2011) Inflammatory bowel disease is associated with poor outcomes of patients with primary sclerosing cholangitis. Clin Gastroenterol Hepatol 9: 1092-1097. [Crossref]

46. Faubion WA Jr., Loftus EV, Sandborn WJ, Freese DK, Perrault J (2001) Pediatric "PSC-IBD": a descriptive report of associated inflammatory bowel disease among pediatric patients with psc. J Pediatr Gastroenterol Nutr 33: 296-300. [Crossref]

47. Donaldson PT, Farrant JM, Wilkinson ML, Hayllar K, Portmann BC, et al. (1991) Dual association of HLA DR2 and DR3 with primary sclerosing cholangitis. Hepatology 13: 129-133. [Crossref]

48. Saarinen S, Olerup O, Broome U (2000) Increased frequency of autoimmune diseases in patients with primary sclerosing cholangitis. Am J Gastroenterol 95: 3195-3199. [Crossref]

49. Donaldson PT, Norris S (2001) Immunogenetics in PSC. Best Pract Res Clin Gastroenterol 15: 611-627. [CrossRef]

50. Terjung B, Spengler U, Sauerbruch T, Worman HJ (2000) "Atypical p-ANCA" in IBD and hepatobiliary disorders react with a 50-kilodalton nuclear envelope protein of neutrophils and myeloid cell lines. Gastroenterology 119: 310-322. [Crossref]

51. Lundqvist K, Broome U (1997) Differences in colonic disease activity in patients with ulcerative colitis with and without primary sclerosing cholangitis: a case control study. Dis Colon Rectum 40: 451-456. [Crossref]

52. Joo M, Abreu-e-Lima P, Farraye F, Smith T, Swaroop P, et al. (2009) Pathologic features of ulcerative colitis in patients with primary sclerosing cholangitis: a casecontrol study. Am J Surg Pathol 33: 854-862. [Crossref]

53. Yarur AJ, Czul F, Levy C (2014) Hepatobiliary manifestations of inflammatory bowel disease. Inflamm Bowel Dis 20: 1655-1667. [CrossRef]

54. Lee YM, Kaplan MM (1995) Primary sclerosing cholangitis. N Engl J Med 332: $924-$ 933. [CrossRef]

55. Palmer KR, Duerden BI, Holdsworth CD (1980) Bacteriological and endotoxin studies in cases of ulcerative colitis submitted to surgery. Gut 21: 851-854. [Crossref]

56. Tanaka H, Leung PS, Kenny TP, Gershwin ME, Bowlus CL (2012) Immunological orchestration of liver fibrosis. Clin Rev Allergy Immunol 43: 220-229. [CrossRef]

57. Pollheimer MJ, Halilbasic E, Fickert P, Trauner M (2011) Pathogenesis of primary sclerosing cholangitis. Best Pract Res Clin Gastroenterol 25: 727-739. [CrossRef]

58. Eksteen B, Mora JR, Haughton EL, Henderson NC, Lee-Turner L, et al. (2009) Gut homing receptors on CD8 $\mathrm{T}$ cells are retinoic acid dependent and not maintained by liver dendritic or stellate cells. Gastroenterology 137: 320-329. [Crossref]
59. Chapman RW, Arborgh BA, Rhodes JM, Summerfield JA, Dick R, et al. (1980) Primary sclerosing cholangitis: a review of its clinical features, cholangiography, and hepatic histology. Gut 21: 870-877. [Crossref]

60. Farrant JM, Hayllar KM, Wilkinson ML, Karani J, Portmann BC, et al. (1991) Natura history and prognostic variables in primary sclerosing cholangitis. Gastroenterology 100: 1710-1717. [Crossref]

61. Broome U, Olsson R, Loof L, Bodemar G, Hultcrantz R, et al. (1996) Natural history and prognostic factors in 305 Swedish patients with primary sclerosing cholangitis. Gut 38: 610-615. [Crossref]

62. Tischendorf JJ, Hecker H, Kruger M, Manns MP, Meier PN (2007) Characterization, outcome, and prognosis in 273 patients with primary sclerosing cholangitis: A single center study. Am J Gastroenterol 102: 107-114. [Crossref]

63. Chapman R, Fevery J, Kalloo A, Nagorney DM, Boberg KM, et al. (2010) Diagnosis and management of primary sclerosing cholangitis. Hepatology 51: 660-678. [CrossRef]

64. Talwalkar JA, Angulo P, Johnson CD, Petersen BT, Lindor KD (2004) Costminimization analysis of MRC versus ERCP for the diagnosis of primary sclerosing cholangitis. Hepatology 40: 39-45. [Crossref]

65. Dave M, Elmunzer BJ, Dwamena BA, Higgins PD (2010) Primary sclerosing cholangitis: meta-analysis of diagnostic performance of MR cholangiopancreatography. Radiology 256: 387-396. [Crossref]

66. Burak KW, Angulo P, Lindor KD (2003) Is there a role for liver biopsy in primary sclerosing cholangitis? Am J Gastroenterol 98: 1155-1158. [Crossref]

67. Ludwig J, Czaja AJ, Dickson ER, LaRusso NF, Wiesner RH (1984) Manifestations of nonsuppurative cholangitis in chronic hepatobiliary diseases: morphologic spectrum, clinical correlations and terminology. Liver 4: 105-116. [Crossref]

68. Lazaridis KN, LaRusso NF (2016) Primary Sclerosing Cholangitis. N Engl J Med 375 1161-1170. [CrossRef]

69. Paumgartner G, Beuers U (2002) Ursodeoxycholic acid in cholestatic liver disease: mechanisms of action and therapeutic use revisited. Hepatology 36: 525-531. [Crossref]

70. Lindor KD (1997) Ursodiol for primary sclerosing cholangitis. Mayo Primary Sclerosing Cholangitis-Ursodeoxycholic Acid Study Group. N Engl J Med 336: 691695. [Crossref]

71. Beuers U, Spengler U, Kruis W, Aydemir U, Wiebecke B, et al. (1992) Ursodeoxycholic acid for treatment of primary sclerosing cholangitis: a placebo-controlled trial. Hepatology 16: 707-714. [Crossref]

72. Olsson R, Boberg KM, de Muckadell OS, Lindgren S, Hultcrantz R, et al. (2005) Highdose ursodeoxycholic acid in primary sclerosing cholangitis: a 5-year multicenter, randomized, controlled study. Gastroenterology 129: 1464-1472. [Crossref]

73. Lindor KD, Kowdley KV, Luketic VA, Harrison ME, McCashland T, et al. (2009) High-dose ursodeoxycholic acid for the treatment of primary sclerosing cholangitis. Hepatology 50: 808-814. [CrossRef]

74. Hirschfield GM, Karlsen TH, Lindor KD, Adams DH (2013) Primary sclerosing cholangitis. Lancet 382: 1587-1599. [CrossRef]

75. Imam MH, Lindor KD (2014) The natural history of primary biliary cirrhosis. Semin Liver Dis 34: 329-333. [CrossRef]

76. Imam MH, Sinakos E, Gossard AA, Kowdley KV, Luketic VA, et al. (2011) High-dose ursodeoxycholic acid increases risk of adverse outcomes in patients with early stage primary sclerosing cholangitis. Aliment Pharmacol Ther 34: 1185-1192. [Crossref]

77. Shi J, Li Z, Zeng X, Lin Y, Xie WF (2009) Ursodeoxycholic acid in primary sclerosing cholangitis: meta-analysis of randomized controlled trials. Hepatol Res 39: 865-873. [CrossRef]

78. Ashraf I, Choudhary A, Arif M, Matteson ML, Hammad HT, et al. (2012) Ursodeoxycholic acid in patients with ulcerative colitis and primary sclerosing cholangitis for prevention of colon cancer: a meta-analysis. Indian J Gastroenterol 31: 69-74. [Crossref]

79. Poropat G, Giljaca V, Stimac D, Gluud C (2011) Bile acids for primary sclerosing cholangitis. Cochrane Database Syst Rev CD003626. [Crossref]

80. Angulo P, Batts KP, Jorgensen RA, LaRusso NA, Lindor KD (2000) Oral budesonide in the treatment of primary sclerosing cholangitis. Am J Gastroenterol 95: 2333-2337. [Crossref]

81. Olsson R, Broome U, Danielsson A, Hägerstrand I, Järnerot G, et al. (1995) Colchicine treatment of primary sclerosing cholangitis. Gastroenterology 108: 1199-1203. [Crossref] 
82. Knox TA1, Kaplan MM (1991) Treatment of primary sclerosing cholangitis with oral methotrexate. Am J Gastroenterol 86: 546-552. [CrossRef]

83. LaRusso NF, Wiesner RH, Ludwig J, MacCarty RL, Beaver SJ, et al. (1988) Prospective trial of penicillamine in primary sclerosing cholangitis. Gastroenterology 95: 1036-1042. [Crossref]

84. Bharucha AE, Jorgensen R, Lichtman SN, LaRusso NF, Lindor KD (2000) A pilot study of pentoxifylline for the treatment of primary sclerosing cholangitis. $\mathrm{Am} \mathrm{J}$ Gastroenterol 95: 2338-2342. [CrossRef]

85. Epstein MP, Kaplan MM (2004) A pilot study of etanercept in the treatment of primary sclerosing cholangitis. Dig Dis Sci 49: 1-4. [CrossRef]

86. Talwalkar JA, Angulo P, Keach JC, Petz JL, Jorgensen RA, et al. (2005) Mycophenolate mofetil for the treatment of primary sclerosing cholangitis. Am J Gastroenterol 100: 308-312. [Crossref]

87. Farkkila M, Karvonen AL, Nurmi H, Nuutinen H, Taavitsainen M, et al. (2004) Metronidazole and ursodeoxycholic acid for primary sclerosing cholangitis: a randomized placebo-controlled trial. Hepatology 40: 1379-1386. [Crossref]

88. Davies YK, Cox KM, Abdullah BA, Safta A, Terry AB, et al. (2008) Long-term treatment of primary sclerosing cholangitis in children with oral vancomycin: an immunomodulating antibiotic. J Pediatr Gastroenterol Nutr 47: 61-67. [Crossref]

89. Silveira MG, Torok NJ, Gossard AA, Keach JC, Jorgensen RA, et al. (2009) Minocycline in the treatment of patients with primary sclerosing cholangitis: results of a pilot study. Am J Gastroenterol 104: 83-88. [Crossref]

90. Beuers U, Kremer AE, Bolier R, Elferink RP (2014) Pruritus in cholestasis: facts and fiction. Hepatology 60: 399-407. [CrossRef]

91. Graziadei IW, Wiesner RH, Batts KP, Marotta PJ, LaRusso NF, et al. (1999) Recurrence of primary sclerosing cholangitis following liver transplantation. Hepatology 29: 10501056. [Crossref]

92. Kim WR, Therneau TM, Wiesner RH, Poterucha JJ, Benson JT, et al. (2000) A revised natural history model for primary sclerosing cholangitis. Mayo Clin Proc 75: 688-694. [Crossref]

93. Rowe IA, Webb K, Gunson BK, Mehta N, Haque S, et al. (2008) The impact of disease recurrence on graft survival following liver transplantation: a single centre experience. Transpl Int 21: 459-465. [Crossref]

94. Cholongitas E, Shusang V, Papatheodoridis GV, Marelli L, Manousou P, et al. (2008) Risk factors for recurrence of primary sclerosing cholangitis after liver transplantation. Liver Transpl 14: 138-143. [Crossref]

95. Alabraba E, Nightingale P, Gunson B, Hubscher S, Olliff S, et al. (2009) A re-evaluation of the risk factors for the recurrence of primary sclerosing cholangitis in liver allografts. Liver Transpl 15: 330-340. [Crossref]

96. Dastis SN, Latinne D, Sempoux C, Geubel AP (2009) Ulcerative colitis associated with $\mathrm{IgG} 4$ cholangitis: similar features in two HLA identical siblings. $J$ Hepatol 51: 601-605. [Crossref]

97. Hirano K, Kawabe T, Yamamoto N, Nakai Y, Sasahira N, et al. (2006) Serum IgG4 concentrations in pancreatic and biliary diseases. Clin Chim Acta 367: 181-184. [Crossref]

98. Mendes FD, Jorgensen R, Keach J, Katzmann JA, Smyrk T, et al. (2006) Elevated serum IgG4 concentration in patients with primary sclerosing cholangitis. $\mathrm{Am} \mathrm{J}$ Gastroenterol 101: 2070-2075. [Crossref]

99. Okazaki K, Uchida K, Koyabu M, Miyoshi H, Takaoka M (2011) Recent advances in the concept and diagnosis of autoimmune pancreatitis and IgG4-related disease. $\mathrm{J}$ Gastroenterol 46: 277-288. [Crossref]

100. Xiao WB, Liu YL (2003) Primary biliary cirrhosis and ulcerative colitis: a case report and review of literature. World J Gastroenterol 9(4):878-880. [Crossref]

101. Koulentaki M, Koutroubakis IE, Petinaki E, Tzardi M, Oekonomaki H, et al. (1999) Ulcerative colitis associated with primary biliary cirrhosis. Dig Dis Sci 44: 19531956. [Crossref]

102. Onishi S, Sakamaki T, Maeda T, Iwamura S, Tomita A, et al. (1994) DNA typing of HLA class II genes; DRB $1 * 0803$ increases the susceptibility of Japanese to primary biliary cirrhosis. J Hepatol 21: 1053-1060. [Crossref]

103. Lever E, Balasubramanian K, Condon S, Wat BY (1993) Primary biliary cirrhosis associated with ulcerative colitis. Am J Gastroenterol 88: 945-947.

104. BH S (1992) Drug-induced hepatic injury. (2ndedn), Elsevier, new York. 1992
105. Kremer JM, Galivan J, Streckfuss A, Kamen B (1986) Methotrexate metabolism analysis in blood and liver of rheumatoid arthritis patients. Association with hepatic folate deficiency and formation of polyglutamates. Arthritis Rheum 29: 832-835. [Crossref]

106. Hirten R, Sultan K, Thomas A, Bernstein DE (2015) Hepatic manifestations of non-steroidal inflammatory bowel disease therapy. World J Hepatol 7: 2716-2728. [Crossref]

107. Taffet SL, Das KM (1983) Sulfasalazine. Adverse effects and desensitization. Dig Dis Sci 28: 833-842. [CrossRef]

108. Teo L, Tan E (2006) Sulphasalazine-induced DRESS. Singapore Med J 47: 237-239 [CrossRef]

109. Rachmilewitz D (1989) Coated mesalazine (5-aminosalicylic acid) versus sulphasalazine in the treatment of active ulcerative colitis: a randomised trial. $B M J$ 298: 82-86. [Crossref]

110. Hautekeete ML, Bourgeois N, Potvin P, Duville L, Reynaert H, et al. (1992) Hypersensitivity with hepatotoxicity to mesalazine after hypersensitivity to sulfasalazine. Gastroenterology 103: 1925-1927. [Crossref]

111. Stoschus B, Meybehm M, Spengler U, Scheurlen C, Sauerbruch T (1997) Cholestasis associated with mesalazine therapy in a patient with Crohn's disease. J Hepatol 26 : 425-428. [Crossref]

112. Nahon S, Cadranel JF, Chazouilleres O, Biour M, Jouannaud V, et al. (2009) Liver and inflammatory bowel disease. Gastroenterol Clin Biol 33: 370-381. [CrossRef]

113. Deltenre P, Berson A, Marcellin P, Degott C, Biour M, et al. (1999) Mesalazine (5-aminosalicylic acid) induced chronic hepatitis. Gut 44: 886-888. [CrossRef]

114. Loftus EV Jr., Kane SV, Bjorkman D (2004) Systematic review: short-term adverse effects of 5-aminosalicylic acid agents in the treatment of ulcerative colitis. Aliment Pharmacol Ther 19: 179-189. [Crossref]

115. Ransford RA, Langman MJ (2002) Sulphasalazine and mesalazine: serious adverse reactions re-evaluated on the basis of suspected adverse reaction reports to the Committee on Safety of Medicines. Gut 51: 536-539. [Crossref]

116. Farrell GC, Larter CZ (2006) Nonalcoholic fatty liver disease: from steatosis to cirrhosis. Hepatology 43: S99-99S112. [CrossRef]

117. Tiede I, Fritz G, Strand S, Poppe D, Dvorsky R, et al. (2003) CD28-dependen Rac1 activation is the molecular target of azathioprine in primary human CD4+ T lymphocytes. J Clin Invest 111: 1133-1145. [CrossRef]

118. Gisbert JP, Gonzalez-Lama Y, Mate J (2007) Thiopurine-induced liver injury in patients with inflammatory bowel disease: a systematic review. Am J Gastroenterol 102: 1518-1527. [Crossref]

119. Bastida G, Nos P, Aguas M, Beltrán B, Rubín A, et al. (2005) Incidence, risk factors and clinical course of thiopurine-induced liver injury in patients with inflammatory bowel disease. Aliment Pharmacol Ther 22: 775-782.

120. Johnston A, Gudjonsson JE, Sigmundsdottir H, Ludviksson BR, Valdimarsson H (2005) The anti-inflammatory action of methotrexate is not mediated by lymphocyte apoptosis, but by the suppression of activation and adhesion molecules. Clin Immunol 114: 154-163. [Crossref]

121. Feagan BG, Fedorak RN, Irvine EJ, Wild G, Sutherland L, et al. (2000) A comparison of methotrexate with placebo for the maintenance of remission in Crohn's disease. North American Crohn's Study Group Investigators. N Engl J Med 342: 1627-1632. [Crossref]

122. Prey S, Paul C (2009) Effect of folic or folinic acid supplementation on methotrexateassociated safety and efficacy in inflammatory disease: a systematic review. $\mathrm{Br} J$ Dermatol 160: 622-628. [Crossref]

123. Barbero-Villares A, Mendoza J, Trapero-Marugan M, Gonzalez-Alvaro I, Daudén E, et al. (2011) Evaluation of liver fibrosis by transient elastography in methotrexate treated patients. Med Clin (Barc) 137: 637-639. [Crossref]

124. Roenigk HH Jr, Auerbach R, Maibach HI, Weinstein GD (1982) Methotrexate guidelines--revised. J Am Acad Dermatol 6: 145-155. [CrossRef]

125. Saag KG, Teng GG, Patkar NM, Anuntiyo J, Finney C, et al. (2008) American College of Rheumatology 2008 recommendations for the use of nonbiologic and biologic disease-modifying antirheumatic drugs in rheumatoid arthritis. Arthritis Rheum 59: 762-784.

126. Jarnerot G, Hertervig E, Friis-Liby I, Blomquist L, Karlén P, et al. (2005) Infliximab as rescue therapy in severe to moderately severe ulcerative colitis: a randomized, placebo-controlled study. Gastroenterology 128: 1805-1811. [Crossref] 
127. Jarrett SJ, Cunnane G, Conaghan PG, Bingham SJ, Buch MH, et al. (2003) Antitumor necrosis factor-alpha therapy-induced vasculitis: case series. J Rheumatol 30 : 2287-2291. [Crossref]

128. Ueno Y, Tanaka S, Shimamoto M, Miyanaka Y, Hiyama T, et al. (2005) Infliximab therapy for Crohn's disease in a patient with chronic hepatitis B. Dig Dis Sci 50: 163-166. [CrossRef]

129. Esteve M, Saro C, Gonzalez-Huix F, Suarez F, Forne M, et al. (2004) Chronic hepatitis B reactivation following infliximab therapy in Crohn's disease patients: need for primary prophylaxis. Gut 53: 1363-1365. [Crossref]

130. Antezana A, Sigal S, Herbert J, Kister I (2015) Natalizumab-induced hepatic injury: A case report and review of literature. Mult Scler Relat Disord 4: 495-498. [Crossref]

131. Bloomgren G, Richman S, Hotermans C, Subramanyam M, Goelz S, et al. (2012) Risk of natalizumab-associated progressive multifocal leukoencephalopathy. $N$ Engl J Med 366: 1870-1880.

132. Soler D, Chapman T, Yang LL, Wyant T, Egan R, et al. (2009) The binding specificity and selective antagonism of vedolizumab, an anti-alpha4beta7 integrin therapeutic antibody in development for inflammatory bowel diseases. $J$ Pharmaco Exp Ther 330: 864-875. [Crossref]

133. Di Bisceglie AM, Lok AS, Martin P, Terrault N, Perrillo RP, et al. (2015) Recent US Food and Drug Administration warnings on hepatitis B reactivation with immunesuppressing and anticancer drugs: just the tip of the iceberg? Hepatology 61: 703711. [Crossref]

134. Hou JK, Velayos F, Terrault N, Mahadevan U (2010) Viral hepatitis and inflammatory bowel disease. Inflamm Bowel Dis 16: 925-932. [CrossRef]

135. Chevaux JB, Bigard MA, Bensenane M, Oussalah A, Jarlot S, et al. (2009) Inflammatory bowel disease and hepatitis B and C. Gastroenterol Clin Biol 33: 10821093. [CrossRef]

136. Zeitz J, Mullhaupt B, Fruehauf H, Rogler G, Vavricka SR (2009) Hepatic failure due to hepatitis $\mathrm{B}$ reactivation in a patient with ulcerative colitis treated with prednisone. Hepatology 50: 653-654. [Crossref]

137. Schiavon LL, Carvalho-Filho RJ, Narciso-Schiavon JL, Barbosa DV, Lanzoni VP, et al. (2008) Impact of cyclosporine-based immunosuppressive therapy on liver histology of hepatitis C virus-infected renal transplant patients. Hepatology 48: 348349. [Crossref]

138. Samonakis DN, Triantos CK, Thalheimer U, Quaglia A, Leandro G, et al. (2005) Immunosuppression and donor age with respect to severity of $\mathrm{HCV}$ recurrence after liver transplantation. Liver Transpl 11: 386-395. [Crossref]

139. Zekry A, Gleeson M, Guney S, McCaughan GW (2004) A prospective cross-over study comparing the effect of mycophenolate versus azathioprine on allograft function and viral load in liver transplant recipients with recurrent chronic HCV infection. Liver Transpl 10: 52-57. [Crossref]

140. Sumer N, Palabiyikoglu M (1995) Induction of remission by interferon-alpha in patients with chronic active ulcerative colitis. Eur J Gastroenterol Hepatol 7: 597602. [Crossref]

141. Musch E, Andus T, Malek M (2002) Induction and maintenance of clinical remission by interferon-beta in patients with steroid-refractory active ulcerative colitis-an open long-term pilot trial. Aliment Pharmacol Ther 16: 1233-1239. [Crossref]

142. Seow CH, Benchimol EI, Griffiths AM, Steinhart AH (2008) Type I interferons for induction of remission in ulcerative colitis. Cochrane Database Syst Rev CD006790. [Crossref]

143. Bargiggia S, Thorburn D, Anderloni A, Ardizzone S, Giorgi A, et al. (2005) Is interferon-alpha therapy safe and effective for patients with chronic hepatitis $\mathrm{C}$ and inflammatory bowel disease? A case-control study. Aliment Pharmacol Ther 22: 209215. [Crossref]

144. Horn TL, Reynolds J, de Villiers W, Pena LR (2009) Hepatitis C virus and inflammatory bowel disease. Dig Dis Sci 54: 1171-1177.

145. Zein NN, Etanercept Study Group (2005) Etanercept as an adjuvant to interferon and ribavirin in treatment-naive patients with chronic hepatitis $\mathrm{C}$ virus infection: a phase 2 randomized, double-blind, placebo-controlled study. J Hepatol 42: 315-322. [Crossref]

146. Wester AL, Vatn MH, Fausa O (2001) Secondary amyloidosis in inflammatory bowel disease: a study of 18 patients admitted to Rikshospitalet University Hospital, Oslo, from 1962 to 1998. Inflamm Bowel Dis 7: 295-300. [Crossref]

147. Greenstein AJ, Sachar DB, Panday AK, Dikman SH, Meyers S, et al. (1992) Amyloidosis and inflammatory bowel disease. A 50-year experience with 25 patients. Medicine (Baltimore) 71: 261-270. [Crossref]
148. Denis MA, Cosyns JP, Persu A, Dewit O, de Galocsy C, et al. (2013) Control of AA amyloidosis complicating Crohn's disease: a clinico-pathological study. Eur J Clin Invest 43: 292-301. [Crossref]

149. 149. Meyers S, Janowitz HD, Gumaste VV, Abramson RG, Berman LJ, et al. (1988) Colchicine therapy of the renal amyloidosis of ulcerative colitis. Gastroenterology 94: 1503-1507. [Crossref]

150. \ Wang Y, Lee H, Shen B (2013) Systemic secondary amyloidosis in a 70-year-old patient with Crohn's disease: treatment with oral budesonide. Inflamm Bowel Dis 19: E74-75. [Crossref]

151. Cabezuelo JB, Egea JP, Ramos F, Torrella E, Muray S, et al. (2012) Infliximab in the treatment of amyloidosis secondary to Crohn's disease. Nefrologia 32: 385-388. [Crossref]

152. Parente F, Pastore L, Bargiggia S, Cucino C, Greco S, et al. (2007) Incidence and risk factors for gallstones in patients with inflammatory bowel disease: a large casecontrol study. Hepatology 45: 1267-1274. [Crossref]

153. Lapidus A, Bangstad M, Astrom M, Muhrbeck O (1999) The prevalence of gallstone disease in a defined cohort of patients with Crohn's disease. Am J Gastroenterol 94: 1261-1266. [Crossref]

154. Hutchinson R, Tyrrell PN, Kumar D, Dunn JA, Li JK, et al. (1994) Pathogenesis of gall stones in Crohn's disease: an alternative explanation. Gut 35: 94-97. [Crossref]

155. Fraquelli M, Losco A, Visentin S, Cesana BM, Pometta R, et al. (2001) Gallstone disease and related risk factors in patients with Crohn disease: analysis of 330 consecutive cases. Arch Intern Med 161: 2201-2204. [Crossref]

156. Ferezou J, Beau P, Parquet M, Champarnaud G, Lutton C, et al. (1993) Cholesterol and bile acid biodynamics after total small bowel resection and bile diversion in humans. Gastroenterology 104: 1786-1795. [Crossref]

157. Brink MA, Slors JF, Keulemans YC, Mok KS, De Waart DR, et al. (1999) Enterohepatic cycling of bilirubin: a putative mechanism for pigment gallstone formation in ileal Crohn's disease. Gastroenterology 116: 1420-1427. [Crossref]

158. Mibu R, Makino I, Chijiiwa K (1995) Gallstones and their composition in patients with ileoanal anastomosis. $J$ Gastroenterol 30: 413-415. [CrossRef]

159. Grainge MJ, West J, Card TR (2010) Venous thromboembolism during active disease and remission in inflammatory bowel disease: a cohort study. Lancet 375: 657-663. [Crossref]

160. Miehsler W, Reinisch W, Valic E, Osterode W, Tillinger W, et al. (2004) Is inflammatory bowel disease an independent and disease specific risk factor for thromboembolism? Gut 53: 542-548. [CrossRef]

161. Yarur AJ, Deshpande AR, Pechman DM, Tamariz L, Abreu MT, et al. (2011) Inflammatory bowel disease is associated with an increased incidence of cardiovascular events. Am J Gastroenterol 106: 741-747. [Crossref]

162. Sinagra E, Aragona E, Romano C, Maisano S, Orlando A, et al. (2012) The role of portal vein thrombosis in the clinical course of inflammatory bowel diseases: report on three cases and review of the literature. Gastroenterol Res Pract 2012: 916428. [Crossref]

163. Irving PM, Pasi KJ, Rampton DS (2005) Thrombosis and inflammatory bowel disease. Clin Gastroenterol Hepatol 3: 617-628. [CrossRef]

164. Spina L, Saibeni S, Battaglioli T, Peyvandi F, de Franchis R, et al. (2005) Thrombosis in inflammatory bowel diseases: role of inherited thrombophilia. Am J Gastroenterol 100: 2036-2041. [Crossref]

165. Jackson LM, O'Gorman PJ, O'Connell J, Cronin CC, Cotter KP, et al. (1997) Thrombosis in inflammatory bowel disease: clinical setting, procoagulant profile and factor V Leiden. QJM 90: 183-188. [Crossref]

166. Baker ME, Remzi F, Einstein D, Oncel M, Herts B, et al. (2003) CT depiction of portal vein thrombi after creation of ileal pouch-anal anastomosis. Radiology 227: 73-79. [Crossref]

167. Remzi FH, Fazio VW, Oncel M, Baker ME, Church JM, et al. (2002) Portal vein thrombi after restorative proctocolectomy. Surgery 132: 655-661; discussion 661652. [Crossref]

168. Ball CG, MacLean AR, Buie WD, Smith DF, Raber EL (2007) Portal vein thrombi after ileal pouch-anal anastomosis: its incidence and association with pouchitis. Surg Today 37: 552-557. [Crossref]

169. Landman C, Nahon S, Cosnes J, Bouhnik Y, Brixi-Benmansour H, et al. (2013) Portomesenteric vein thrombosis in patients with inflammatory bowel disease. Inflamm Bowel Dis 19: 582-589. [CrossRef] 
170. Kopylov U, Amitai MM, Lubetsky A, Eliakim R, Chowers Y, et al. (2012) Clinical and radiographic presentation of superior mesenteric vein thrombosis in Crohn's disease: a single center experience. J Crohns Colitis 6: 543-549. [Crossref]

171. Maconi G1, Bolzacchini E, Dell'Era A, Russo U, Ardizzone S, et al. (2012) Portal vein thrombosis in inflammatory bowel diseases: a single-center case series. J Crohns Colitis 6: 362-367. [CrossRef]

172. Bernstein CN, Sargent M, Vos HL, Rosendaal FR (2007) Mutations in clotting factors and inflammatory bowel disease. Am J Gastroenterol 102: 338-343. [Crossref]

173. Danese S, Papa A, Saibeni S, Repici A, Malesci A, et al. (2007) Inflammation and coagulation in inflammatory bowel disease: The clot thickens. Am J Gastroenterol 102: 174-186. [Crossref]

174. Vassiliadis T, Mpoumponaris A, Giouleme O, Hatzidakis A, Patsiaoura K, et al. (2009) Late onset ulcerative colitis complicating a patient with Budd-Chiari syndrome: a case report and review of the literature. Eur J Gastroenterol Hepatol 21: 109-113. [Crossref]

175. Socha P, Ryzko J, Janczyk W, Dzik E, Iwanczak B, et al. (2007) Hepatic vein thrombosis as a complication of ulcerative colitis in a 12 -year-old patient. Dig Dis Sci 52: 1293-1298. [Crossref]

176. Molina Infante J, Banares Canizares R, Gomez Camarero J, Perez Calle JL (2004) [Liver abscess and Crohn' disease. Report of 3 cases]. Gastroenterol Hepatol 27: 317-319. [Crossref]

177. Bernabeu JL, Leo E, Trigo C, Herrera JM, Sousa JM, et al. (2011) Crohn's disease and liver abscess due to Pediococcus sp. Inflamm Bowel Dis 17: 2207-2208. [Crossref]

178. Aguas M, Bastida G, Nos P, Beltran B, Grueso JL, et al. (2007) Septic thrombophlebitis of the superior mesenteric vein and multiple liver abscesses in a patient with Crohn's disease at onset. BMC Gastroenterol 7: 22. [Crossref]

179. Vakil N, Hayne G, Sharma A, Hardy DJ, Slutsky A (1994) Liver abscess in Crohn's disease. Am J Gastroenterol 89: 1090-1095.

180. Mir-Madjlessi SH, McHenry MC, Farmer RG (1986) Liver abscess in Crohn's disease. Report of four cases and review of the literature. Gastroenterology 91: 987993. [Crossref]

181. Bermejo F, Lopez-Sanroman A, Taxonera C, Gisbert JP, Pérez-Calle JL, et al (2008) Acute pancreatitis in inflammatory bowel disease, with special reference to azathioprine-induced pancreatitis. Aliment Pharmacol Ther 28: 623-628. [Crossref]

182. Grandval P, Barthet M, Desjeux A, Garcia S, Boustiere C, et al. (2001) Pseudotumorous chronic pancreatitis associated with inflammatory bowel disease. Dig Dis Sci 46: 898-900. [Crossref]

183. Sahel J, Barthet M, Gasmi M (2004) Autoimmune pancreatitis: increasing evidence for a clinical entity with various patterns. Eur J Gastroenterol Hepatol 16: 12651268. [Crossref]

184. Ravi K, Chari ST, Vege SS, Sandborn WJ, Smyrk TC, et al. (2009) Inflammatory bowel disease in the setting of autoimmune pancreatitis. Inflamm Bowel Dis 15: 1326-1330. [Crossref]

185. Barthet M, Lesavre N, Desplats S, Panuel M, Gasmi M, et al. (2006) Frequency and characteristics of pancreatitis in patients with inflammatory bowel disease. Pancreatology 6: 464-471. [Crossref]

186. Ramji A, Owen DA, Erb SR, Scudamore CH, Yoshida EM (2002) Post-liver transplant Crohn's disease: graft tolerance but not self-tolerance? Dig Dis Sci 47: 522-527. [CrossRef]

187. Worns MA, Lohse AW, Neurath MF, Croxford A, Otto G, et al. (2006) Five cases of de novo inflammatory bowel disease after orthotopic liver transplantation. $\mathrm{Am} J$ Gastroenterol 101: 1931-1937. [Crossref]

188. Hampton DD, Poleski MH, Onken JE (2008) Inflammatory bowel disease following solid organ transplantation. Clin Immunol 128: 287-293. [Crossref]

189. Nepal S, Navaneethan U, Bennett AE, Shen B (2013) De novo inflammatory bowel disease and its mimics after organ transplantation. Inflamm Bowel Dis 19: 1518-1527. [Crossref]
190. Sakamoto T, Sato Y, Yamamoto S, Oya H, Hatakeyama K (2012) De novo ulcerative colitis and autoimmune hepatitis after living related liver transplantation from cytomegalovirus-positive donor to cytomegalovirus-negative recipient: a case report. Transplant Proc 44: 570-573. [Crossref]

191. Riley TR, Schoen RE, Lee RG, Rakela J (1997) A case series of transplant recipients who despite immunosuppression developed inflammatory bowel disease. Am J Gastroenterol 92: 279-282. [Crossref]

192. Papatheodoridis GV, Hamilton M, Mistry PK, Davidson B, Rolles K, Burroughs AK Ulcerative colitis has an aggressive course after orthotopic liver transplantation for primary sclerosing cholangitis. Gut 43: 639-644. [Crossref]

193. Verdonk RC, Dijkstra G, Haagsma EB, Shostrom VK, Van den Berg AP, et al Inflammatory bowel disease after liver transplantation: risk factors for recurrence and de novo disease. Am J Transplant 6: 1422-1429. [Crossref]

194. MacLean AR, Lilly L, Cohen Z, O'Connor B, McLeod RS (2003) Outcome of patients undergoing liver transplantation for primary sclerosing cholangitis. Dis Colon Rectum 46: 1124-1128. [Crossref]

195. Moncrief KJ, Savu A, Ma MM, Bain VG, Wong WW, et al. (2010) The natura history of inflammatory bowel disease and primary sclerosing cholangitis afte liver transplantation--a single-centre experience. Can J Gastroenterol 24: 40-46. [Crossref]

196. Befeler AS, Lissoos TW, Schiano TD, Conjeevaram H, Dasgupta KA, et al (1998) Clinical course and management of inflammatory bowel disease after liver transplantation. Transplantation 65: 393-396. [Crossref]

197. Joshi D, Bjarnason I, Belgaumkar A, O'Grady J, Suddle A, et al. (2013) The impact of inflammatory bowel disease post-liver transplantation for primary sclerosing cholangitis. Liver Int 33: 53-61. [Crossref]

198. Reddy SS, Brandt LJ (2013) Clostridium difficile infection and inflammatory bowel disease. J Clin Gastroenterol 47: 666-671.

199. Dvorchik I, Subotin M, Demetris AJ, Fung JJ, Starzl TE, et al. (2002) Effect of liver transplantation on inflammatory bowel disease in patients with primary sclerosing cholangitis. Hepatology 35: 380-384. [Crossref]

200. Haagsma EB, Van Den Berg AP, Kleibeuker JH, Slooff MJ, Dijkstra G (2003) Inflammatory bowel disease after liver transplantation: the effect of different immunosuppressive regimens. Aliment Pharmacol Ther 18: 33-44. [Crossref]

201. Navaneethan U, Choudhary M, Venkatesh PG, Lashner BA, Remzi FH, et al. (2012) The effects of liver transplantation on the clinical course of colitis in ulcerative colitis patients with primary sclerosing cholangitis. Aliment Pharmacol Ther 35: 1054 1063. [Crossref]

202. Buell JF, Gross TG, Woodle ES (2005) Malignancy after transplantation. Transplantation 80: S254-264.

203. Hanouneh IA, Macaron C, Lopez R, Zein NN, Lashner BA (2012) Risk of colonic neoplasia after liver transplantation for primary sclerosing cholangitis. Inflamm Bowel Dis 18: 269-274. [Crossref]

204. Navaneethan U, Venkatesh PG, Mukewar S, Lashner BA, Remzi FH, et al. (2012) Progressive primary sclerosing cholangitis requiring liver transplantation is associated with reduced need for colectomy in patients with ulcerative colitis. Clin Gastroenterol Hepatol 10: 540-546. [Crossref]

205. Loftus EV Jr., Harewood GC, Loftus CG, Tremaine WJ, Harmsen WS, et al. (2005) PSC-IBD: a unique form of inflammatory bowel disease associated with primary sclerosing cholangitis. Gut 54: 91-96. [Crossref]

206. Singh S, Loftus EV, Jr., Talwalkar JA (2013) Inflammatory bowel disease after liver transplantation for primary sclerosing cholangitis. Am J Gastroenterol 108 $1417-1425$.

207. European Association for the Study of the L (2009) EASL Clinical Practice Guidelines: management of cholestatic liver diseases. J Hepatol 51: 237-267. [Crossref]

Copyright: (C2017 Shah NJ. This is an open-access article distributed under the terms of the Creative Commons Attribution License, which permits unrestricted use, distribution, and reproduction in any medium, provided the original author and source are credited. 